\title{
STUDI ANALISIS PERKEMBANGAN TEKNOLOGI DAN DUKUNGAN PEMERINTAH INDONESIA TERKAIT MOBIL LISTRIK
}

\author{
Mochammad Aziz ${ }^{1}$ \\ Program Studi Teknik Elektro President University \\ Email: akuazizmochammad@gmail.com \\ Yosua Marcellino ${ }^{1}$ \\ Program Studi Teknik Elektro President University \\ Email: yosuaelin3@gmail.com \\ Intan Agnita Rizki ${ }^{1}$ \\ Program Studi Teknik Elektro President University \\ Email: intanagnita042@gmail.com \\ Sri Anwar Ikhwanuddin ${ }^{1}$ \\ Program Studi Teknik Elektro President University \\ Email: srianwarikhwanuddin@yahoo.com \\ Joni Welman Simatupang ${ }^{1}$ \\ Program Studi Teknik Elektro President University \\ Email: joniws@ieee.org
}

\begin{abstract}
Indonesia's population growth is still ongoing and energy demand for transportation continues to increase from year to year. Moreover, the use of fossil fueled-based motor vehicle is increasing and filling the city main roads and highways. Petroleum which is used as conventional vehicle fuel today is a non-renewable energy. Electric vehicle is one of the means of transportation that can meet the needs of the society mobility, but still environmentally friendly because it does not have exhaust gas or emissions. There are so many negative effects from exhaust gas or emissions resulting from combustion of conventional car engines. Among other negative impacts are on health and human well-being and also the environment. The Indonesian government plans seriously in realizing the conversion of electric-based vehicles (EV). However, many people do not know the technology used in the electric vehicle yet. In this descriptive-explanatory paper, we will discuss this technology development and types of electric vehicle in general, and also a bit of autonomous vehicle. In addition, it was also discussed regarding the support of the Indonesian government for public concerns about the lack of facilities for electric vehicle such as public charging facilities. In addition, support for policies and other incentive will also be elaborated in this paper. This policies and incentive are expected to have a significant impact in-line with the increasing of consumer awareness to switch from conventional cars to electric vehicles.
\end{abstract}

Keywords: Technology; Electric vehicle; Government support, Fossil fueled-based vehicle.

\begin{abstract}
ABSTRAK : Pertumbuhan penduduk Indonesia masih terus berlangsung dan kebutuhan energi untuk transportasi terus meningkat dari tahun ke tahun. Terlebih penggunaan kendaraan bermotor berbahan bakar fosil (fossil fueled-based motor vehicle) semakin meningkat dan memenuhi jalan-jalan raya perkotaan dan tol. Minyak bumi yang digunakan sebagai bahan bakar mobil konvensional saat ini merupakan energi yang tidak terbarukan. Mobil listrik merupakan salah satu sarana transportasi yang bisa memenuhi kebutuhan mobilitas masyarakat namun tetap ramah lingkungan karena tidak memiliki polusi atau emisi gas buang. Banyak sekali dampak negatif dari polusi atau emisi gas buang yang dihasilkan dari pembakaran mesin mobil konvensional. Antara lain dampak negatif terhadap kesehatan dan kesejahteraan manusia serta lingkungan hidup. Pemerintah Indonesia berencana serius dalam mewujudkan konversi kendaraan berbasis listrik (KBL). Namun masyarakat belum mengetahui teknologi yang digunakan pada mobil listrik. Dalam tulisan yang bersifat descriptive- explanatory ini akan dibahas mengenai perkembangan teknologi mobil listrik ditambah sedikit tentang kendaraan otomatis (autonomous vehicle). Selain itu juga akan membahas dukungan pemerintah Indonesia terhadap mobil listrik sebagai solusi bagi kekuatiran masyarakat mengingat fasilitas pengisian umum yang masih minim atas kendaraan mobil listrik. Selain itu dukungan terhadap kebijakan dan insentif lainnya pun juga akan dibahas dalam artikel ini. Kebijakan dan insentif ini diharapkan bisa berdampak signifikan sejalan dengan meningkatnya kesadaran konsumen untuk beralih dari mobil konvensional menjadi mobil listrik.

Kata Kunci: Teknologi; Mobil listrik; Dukungan pemerintah, Kendaraan berbahan bakar fosil.
\end{abstract}

\section{PENDAHULUAN}

khir-akhir ini pemerintah Indonesia sangat mendorong penggunaan mobil listrik. Seperti yang pernah disampaikan oleh Presiden Joko Widodo pada acara tahunan industri jasa keuangan tahun 2020 di grand ballroom The Ritz Carlton Pacific Place (PP) Jakarta, bahwa hanya mobil listrik saja yang

\footnotetext{
${ }^{1}$ Program Studi Teknik Elektro President University
} 
suatu saat nanti diperbolehkan berlalu-lalang di ibu kota baru [1]. Situs CNN Indonesia yang berjudul "Arahan Jokowi, Ibu Kota Baru Eksklusif Mobil Listrik-Otonom" itu, memberitakan tentang kebijakan mobil listrik yang akan diterapkan pada ibu kota baru Indonesia. Kebijakan tersebut juga berisi tentang larangan penggunaan kendaraan bermotor konvensional dalam kawasan ibu kota baru Indonesia.

Pernyataan Presiden tersebut di atas diberikan berdasarkan data yang dirilis oleh Badan Pusat Statistik (BPS) bahwa jenis kendaraan bermotor di Indonesia telah mencapai 146,8 juta unit pada tahun 2018, di mana 16,4 juta unit merupakan mobil penumpang [2]. Hal ini menyebabkan terjadinya peningkatan yang signifikan atas bahan bakar fosil yang dikonsumsi oleh masyarakat Indonesia, yang akan berakibat pula pada meningkatnya polusi gas buang dari kendaraan bermotor. Kota Jakarta pernah menempati urutan kedua tingkat (level) udara paling berpolusi di dunia menurut situs AirVisual (airvisual.com) pada bulan Agustus 2019 [3].

Salah satu solusi dalam mengurangi penggunaan kendaraan bermotor (berbahan bakar fosil) ialah dengan beralih ke kendaraan berbasis listrik (KBL) seperti mobil listrik. Mobil listrik memiliki beberapa keunggulan dibandingkan kendaraan bermotor berbahan bakar fosil (fossil fueled-based vehicle), dan salah satunya (yang utama) ialah tidak dihasilkannya gas buang sehingga tidak memberikan sumbangsih/kontribusi bagi pemanasan global (carbon footprint) di Indonesia [4]. Dukungan pemerintah Indonesia terhadap mobil listrik tercantum dalam Perpres No. 55 Tahun 2019 tentang Percepatan Program Berbasis Baterai untuk Transportasi Jalan. Di dalamnya juga dibahas tentang insentif yang akan diberikan untuk mendorong percepatan konversi kendaraan berbasis listrik.

Dalam jurnal yang terdapat pada situs MDPI (Multidisciplinary Digital Publishing Institute) berjudul "A Comprehensive Study of Key Electric Vehicle (EV) Components, Technologies" disebutkan bahwa sesungguhnya mobil listrik bukanlah sebuah teknologi baru dalam dunia otomotif [5]. Namun, sesungguhnya masih banyak masyarakat Indonesia yang belum mengetahui tentang teknologi mobil listrik. Tulisan ini berusaha untuk membagikan pengetahuan kepada masyarakat umum supaya lebih mengerti tentang teknologi ini (di mana bagian ini akan selanjutnya dideskripsikan dan dibahas di Bab 3) dan di masa depan bisa ikut mensukseskan rencana pemerintah Indonesia dalam memasyarakatkan kendaraan berbasis listrik, khususnya mobil listrik.

\section{Tujuan Penelitian}

Berdasarkan latar belakang tersebut, maka tujuan dari studi ini adalah untuk mengedukasi masyarakat tentang perkembangan teknologi mobil listrik dan bagaimana dukungan pemerintah Indonesia terhadap keberadaan kendaraan bermotor/berbasis listrik (KBL) seperti mobil listrik dalam mengurangi dampak pemanasan global (global climate change and carbon footprint).

\section{Rumusan Masalah}

Berikut rumusan masalah yang akan dibahas:

- Bagaimana sejarah perkembangan teknologi mobil listrik?

- Apa saja dukungan pemerintah Indonesia terhadap mobil listrik?

- Jika ada, apa saja kelemahan mobil listrik dibandingkan dengan mobil konvensional?

\section{METODE DAN MATERIAL}

Metodologi penelitian ini adalah survei literatur dari Internet (secondary resources). Dalam studi survei yang digunakan adalah Systematic Literature Review (SLR). Dalam proses pencariannya digunakan dua kata kunci. Kata kunci pertama adalah "Electrical Vehicle". Hasil yang muncul dalam pencarian kata kunci pertama mencapai lebih dari tiga juta buku, artikel atau jurnal. Selanjutnya kata kunci yang kedua adalah "Dukungan Pemerintah Indonesia Terhadap Mobil Listrik". Beberapa sumber yang didapatkan meliputi jurnal artikel dan buku mencapai 2,8 juta judul buku dan artikel jurnal. Sedangkan bila difokuskan hanya kepada file-file $p d f$, hanya mencapai 400 ribu judul. Kata kunci lain yang digunakan adalah "Perpres No. 55 Tahun 2019 tentang Percepatan Program Berbasis Baterai untuk Transportasi Jalan", yang hasil pencariannya sebanyak 44 ribu judul.

Pencarian difokuskan pada artikel-artikel yang terbit di sejumlah jurnal ilmiah bereputasi. Namun selain itu, ada juga beberapa artikel pada situs-situs web yang dapat diandalkan. Dari hasil 
pencarian tersebut, selanjutnya akan dilakukan filtering untuk mendapatkan banyak sumber yang penting bahkan terpenting demi tuntasnya penelitian dan penulisan topik ini.

\section{HASIL PEMBAHASAN (STUDI ANALISIS)}

\section{Sejarah Singkat Perkembangan Mobil Listrik}

Sejatinya inovasi penggunaan mobil listrik pertama telah diperkenalkan pada tahun 1828 dan diproduksi pertama pada tahun 1884. Pada tahun 1897-1900 terdapat 28\% mobil listrik dari total kendaraan yang ada di pasaran. Pada saat itu mobil listrik lebih digemari namun mobil dengan bahan bakar minyak mendapatkan kesempatan untuk mencuri pasar disebabkan harga minyak dunia yang masih rendah. Mobil listrik pun terlupakan dan ditinggalkan hingga pada tahun 1996 muncul sebuah konsep EV1 dari General Motors yang sangat popular dan menjadi salah satu momen kebangkitan mobil listrik. Kesuksesan General Motors pun mendorong pembuat mobil terkemuka lainnya untuk ikut dalam memperkenalkan produknya di sektor mobil listrik termasuk di antaranya Ford, Toyota, dan Honda dengan keunggulannya masing-masing.

Toyota dengan produknya Prius (Gambar 1) yang merupakan mobil hibrid komersial pertama yang diluncurkan pada tahun 1997 di Jepang, sangat sukses dengan total penjualan 18.000 unit pada tahun pertama produksi. Untuk saat ini pasar mobil listrik didominasi oleh Nissan Leaf, Chevrolet Volt, dan Tesla Model S, sedangkan pasar Cina dalam cengkeraman BYD Auto Co, Ltd (Xi'an Nasional Hitech Zona Pengembangan Industri, Xian, Cina). [5]

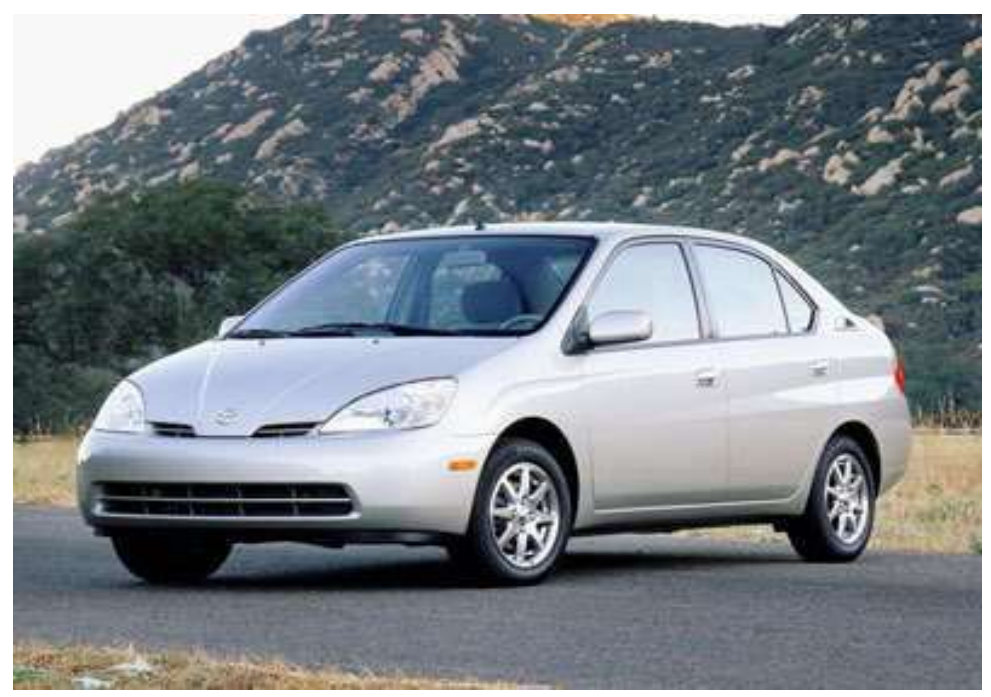

Gambar 1. Toyota Prius sebagai mobil listrik hibrid komersil pertama di Asia.

Diluncurkan pada tahun 1997 di Jepang [6].

\section{Perkembangan Teknologi Mobil Listrik}

Memiliki baterai sebagai sumber energi utama merupakan dasar dari mobil listrik. Namun, saat ini yang lebih berkembang adalah penggunaan baterai dan bahan bakar minyak bersama-sama untuk menggerakkan sebuah mobil. Konsep ini lebih dikenal dengan sebutan hibrid. Secara garis besar kita mengenal dua jenis utama dari mobil listrik yaitu Battery Electric Vehicle (BEV) dan Plug-in Hibrid Electric Vehicle (PHEV), yang akan dijelaskan secara detail dari segi jenis/tipenya satu persatu [7].

\section{Battery Electric Vehicle (BEV)}

Hanya mengandalkan energi yang tersimpan dalam kemasan baterai, mobil listrik jenis BEV dapat menjangkau jarak tempuh 100 sampai $250 \mathrm{~km}$ dalam sekali pengisian daya penuh. Untuk kelas yang lebih tinggi, jarak tempuh bisa lebih jauh mencapai 300 sampai $500 \mathrm{~km}$ [8]. Rentang jarak tempuh ini juga dipengaruhi oleh kondisi dan gaya usia pengemudi, kondisi jalan, iklim, dan jenis baterai. Karena hanya mengandalkan daya yang tersimpan di baterai, mobil listrik jenis BEV tidak mengeluarkan emisi seperti karbon dioksida $\left(\mathrm{CO}_{2}\right)$ dan emisi polutan lainnya, seperti logam berat, yaitu zat timbal $(\mathrm{Pb})$.

Ada berbagai macam baterai yang diterapkan pada mobil listrik. Gambar 2 ini menampilkan sebuah diagram/plot ragone dari beberapa teknologi baterai yang lebih umum, yang digunakan untuk 
membandingkan kepadatan energi berbagai (ukuran dan berat) perangkat penyimpanan energi, mulai dari Lead-acid, Ni-Cd, Ni-MH, Li ion (PLiON), dan Li metal (smaller size and lighter weight).

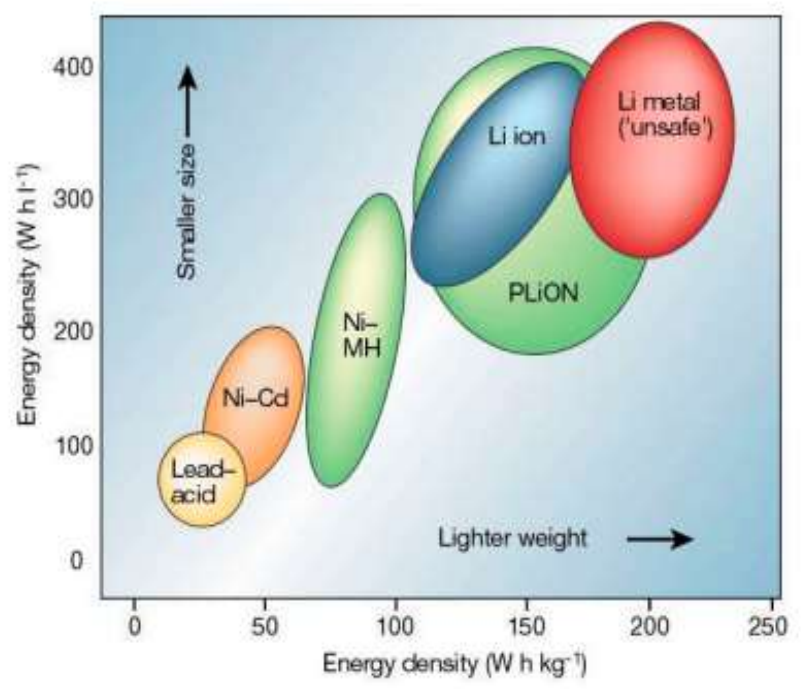

םambar 2. Plot ragone dari beberapa teknologi baterai yang digunakan dalam mobil listrik [9].

Baterai pada dasarnya adalah media penyimpanan yang terdiri dari dua elektroda pada elektrolit. Elektrolit ini menyediakan media untuk pertukaran ion yang menghasilkan listrik. Masing-masing baterai yang ditunjukkan pada Gambar 2 memiliki kelebihan dan kekurangan unik mereka masingmasing, meskipun inovasi terbaru dalam baterai Li-ion telah mendorong mereka untuk menjadi pemimpin pasar untuk digunakan di sebagian besar elektronik genggam dan portabel serta kendaraan listrik. Hal ini terutama karena energi spesifik mereka (Wh/kg), siklus hidup (life-cycle), dan efisiensi yang tinggi. Mereka memiliki kelemahan yang meliputi biaya yang tinggi dan kebutuhan untuk keselamatan kompleks dan sistem pemantauannya [9].

\section{Plug-in Hibrid Electrical Vehicle (PHEV)}

Berbeda dengan BEV yang hanya mengandalkan energi dari penyimpanan baterai, kendaraan listrik berjenis Plug-in Hibrid Electrical Vehicle (PHEV) memiliki fleksibilitas yang lebih dalam hal sumber bahan bakar. Tentu PHEV memiliki sumber energi listrik yang di simpan pada baterai namun selain itu PHEV juga bisa dijalankan dengan menggunakan sumber energi dari pembakaran bahan bakar minyak. Ini menjadi salah satu keunggulan kendaraan listrik jenis PHEV. Dalam sebuah studi diperkirakan bahwa PHEV yang dijalankan sejauh 40 mil hanya dengan menggunakan sumber energi listrik maka akan sebanding dengan $45 \%$ pemakaian mesin dengan menggunakan sumber energi dari minyak bumi [10].

Berdasarkan dari penggabungan mesinnya, PHEV dapat dibedakan menjadi 3 jenis yaitu : hibrid seri, hibrid paralel, dan hibrid gabungan (kombinasi seri dan paralel).

\section{Jenis pertama: Hibrid Seri}

Dalam sistem hibrid seri, mesin pembakaran tidak langsung memutarkan roda melainkan motor listrik satu-satunya sarana untuk memberikan daya ke roda. Ketika listrik diperlukan dalam jumlah besar, maka motor akan menarik listrik dari baterai dan generator. Konfigurasi hibrid seri sudah lama ada, contohnya: lokomotif diesel-listrik, mesin pengolah tanah hidrolik, kelompok tenaga diesel-listrik. Gambar 3 menampilkan struktur kendaraan PHEV dalam sistem hibrid seri. Contoh mobil jenis ini adalah Renault Kangoo. 

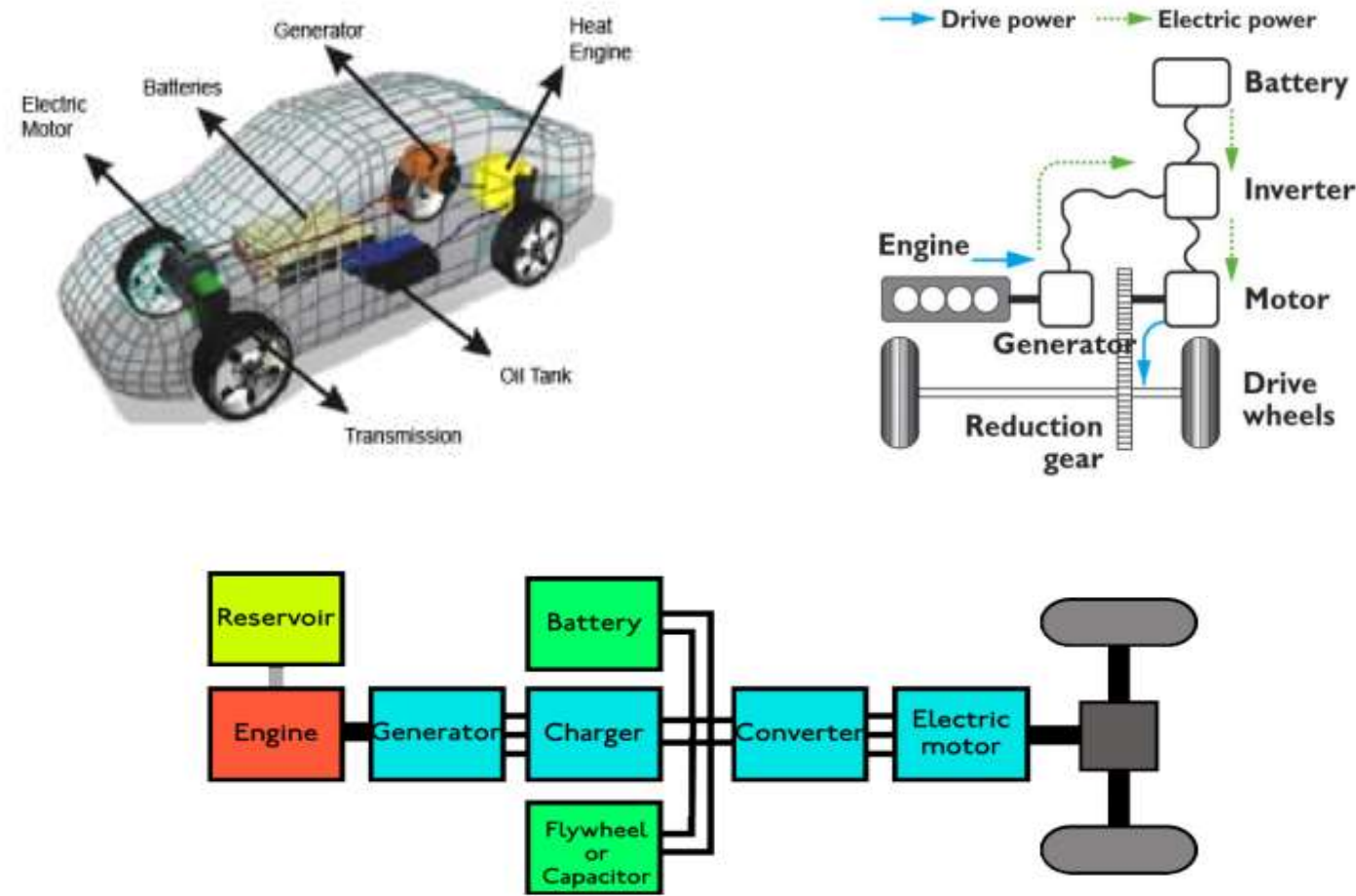

Gambar 3. Struktur kendaraan PHEV dalam sistem hibrid seri [11].

Kelemahan dari kendaraan hibrid seri ini meliputi:

- Mesin pembakaran, generator dan motor listrik berperan penuh dalam kendaraan. Oleh karena itu, berat total, biaya dan ukuran power train cukup besar.

- Kekuatan dari mesin pembakaran harus dijalankan melalui generator dan motor listrik. Jika digunakan untuk jarak jauh, maka total efisiensinya lebih rendah daripada mobil konvensional.

Sedangkan keuntungan dari kendaraan hibrid seri ini antara lain:

- Tidak ada hubungan mekanis antara mesin pembakaran dan roda. Kelompok mesin generator dapat ditemukan di mana-mana.

- Ada unsur-unsur mekanik transmisi konvensional motor roda listrik yang terpisah dan dapat diimplementasikan dengan mudah.

- Mesin pembakaran dapat beroperasi dalam rentang rpm (rotation per minute) yang sempit bahkan saat mobil berubah kecepatan, mobil hibrid seri relatif paling efisien selama stop-andgo mengemudi dalam perkotaan.

\section{Jenis kedua: Hibrid Pararel}

Sistem hibrid paralel memiliki mesin pembakaran internal dan sebuah motor listrik secara paralel terhubung ke transmisi mekanik seperti ditunjukkan pada Gambar 4. Baterai dapat diisi ulang selama berkendara. Sedangkan hubungan mekanisnya adalah tetap antara roda dan motor, dan tidak ada kopling, di mana baterai tidak dapat diisi ketika mobil tidak bergerak. Beberapa jenis dari mobil listrik paralel adalah Honda Civic dan BMW ActiveHibrid 7series. 

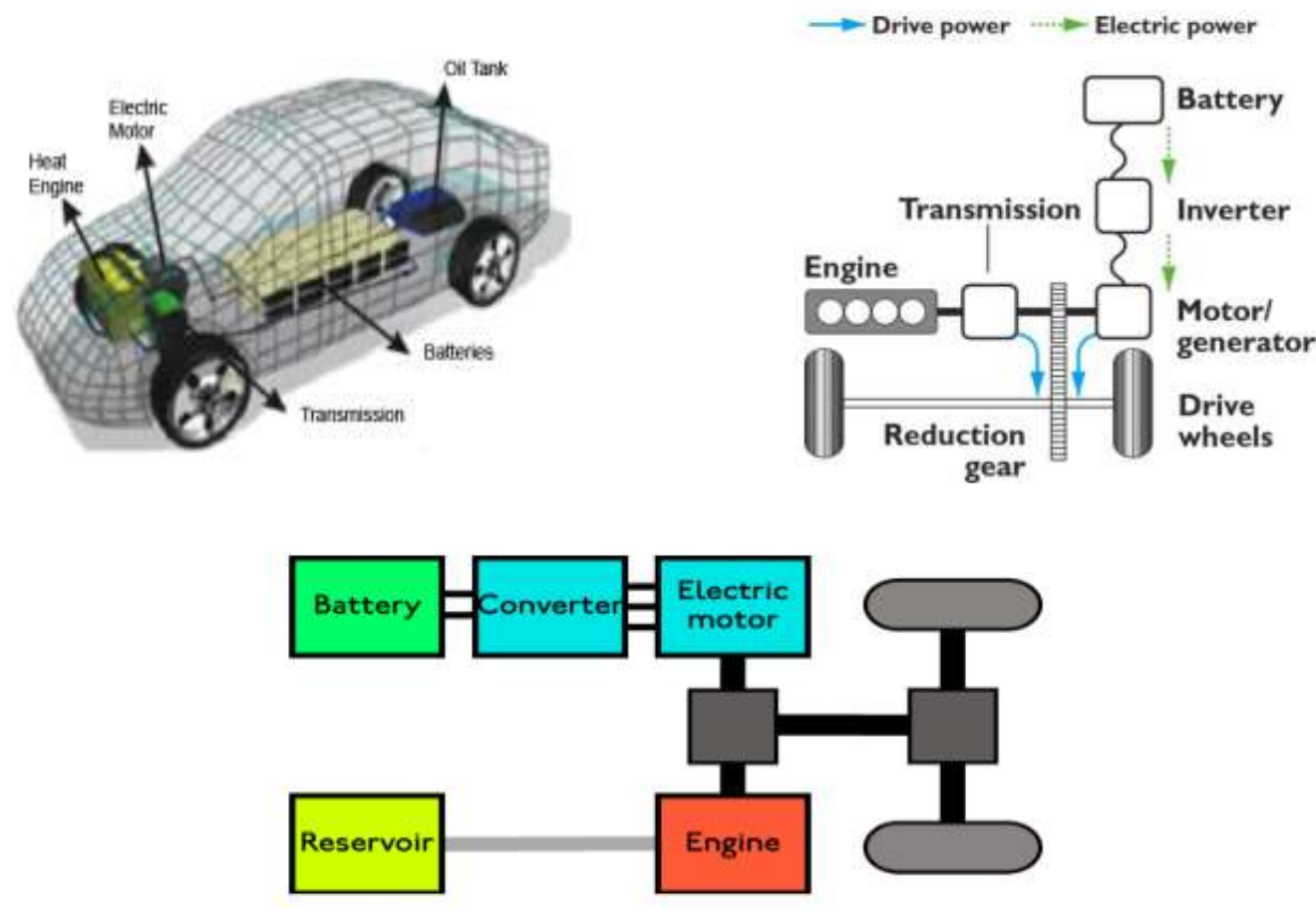

Gambar 4. Struktur kendaraan PHEV dalam sistem hibrid paralel [11].

Konfigurasi paralel memiliki modus operasi yang beragam seperti yang ditampilkan pada Gambar 5.

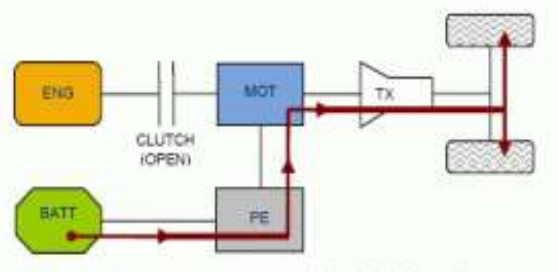

(a): electric only,

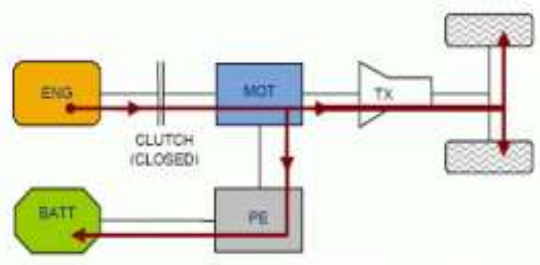

(c): battery charging

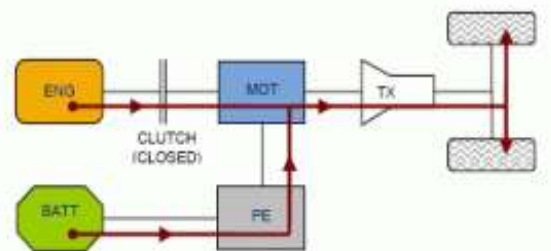

(b): hybrid / electric assist.

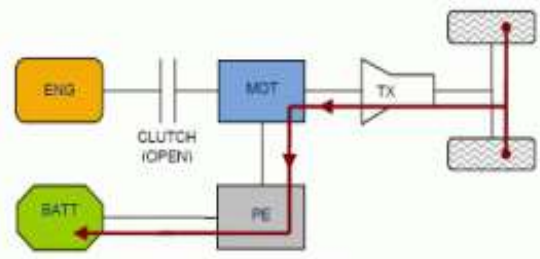

(d): regenerative braking

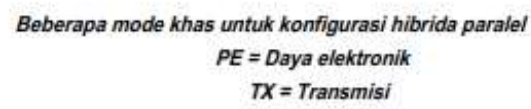

Gambar 5. Empat konfigurasi PHEV dalam sistem hibrid pararel. (a) tenaga listrik saja, kecepatan maksimal $40 \mathrm{~km} / \mathrm{jam}$, cocok sebagai city car. (b) mesin pembakaran dan tenaga listrik. (c) mesin pembakaran dan pengisian baterai. (d) regeneratif breaking, di mana motor listrik mengambil keuntungan dari energi kinetik kendaran yang bergerak untuk bertindak sebagai generator [11]. 
Ada beberapa kelemahan untuk kendaraan hibrid paralel, diantaranya:

- Sistem yang rumit.

- Mesin pembakaran tidak beroperasi dalam rentang rpm (rotation per minute) yang sempit atau konstan, sehingga efisiensi pada kecepatan putaran menjadi rendah.

- Mesin pembakaran tidak terpisah dari roda, menyebabkan baterai tidak dapat diisi saat berhenti.

Sedangkan beberapa keuntungan dari kendaraan jenis hibrid paralel ini adalah:

- Total efisiensinya tinggi selama berkendara jarak jauh.

- Fleksibilitasnya tinggi untuk beralih antara tenaga listrik dan mesin pembakaran.

- Kekuatannya dapat dirancang lebih kecil dibandingkan mesin pembakaran karena hanya satu motor listrik atau generator yang diperlukan.

\section{Jenis ketiga: Hibrid Gabungan}

Sistem hibrid gabungan memiliki fitur dari kedua seri dan paralel. Ada sebuah koneksi ganda antara mekanik dan listrik. Kekuatan untuk menggerakkan roda dapat berupa mekanik atau listrik dan juga bisa keduanya. Hal ini juga terjadi di hibrid paralel. Tapi prinsip utama di balik sistem gabungan adalah meminimalisir kebutuhan dari daya yang disediakan oleh mesin. Gambar 6 menunjukkan struktur kendaraan PHEV dalam sistem hibrid gabungan. Beberapa contoh jenis ini adalah Toyota Prius, Auris, Lexus CT200h, Lexus RX400h.

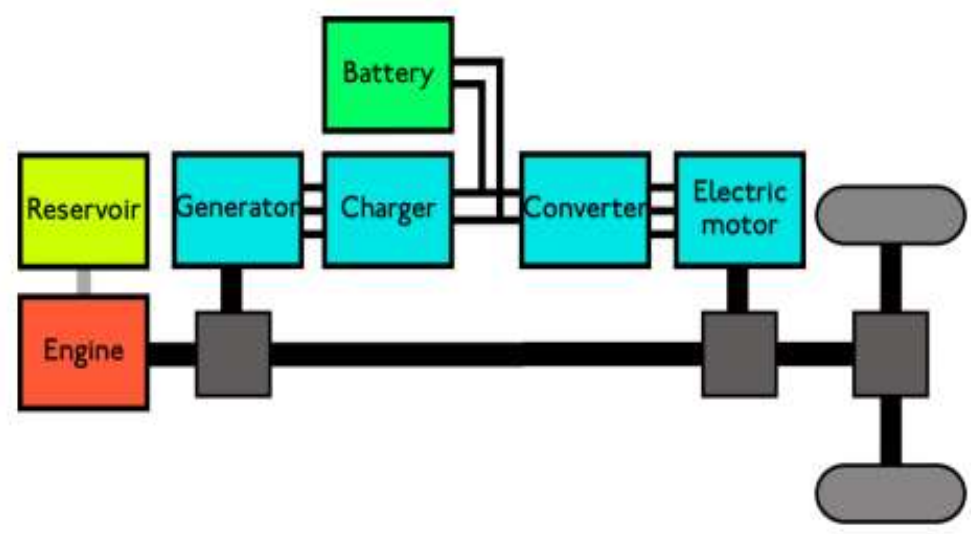

Gambar 6. Struktur kendaraan PHEV dalam sistem hibrid gabungan [11].

Kelemahan dari kendaraan hibrid gabungan adalah:

- Sistem yang sangat rumit, dan lebih mahal daripada hibrid paralel.

- Efisiensi transmisi power train tergantung pada jumlah daya yang dikirim melalui jalur listrik, seperti beberapa konversi masing-masing dengan efisiensi mereka sendiri menyebabkan efisiensi yang lebih rendah $(\sim 70 \%)$ dibandingkan dengan jalur murni mekanis $(\sim 98 \%)$.

Sedangkan keuntungannya meliputi:

- Memiliki fleksibilitas maksimum untuk beralih antara tenaga listrik dan mesin pembakaran.

- Menekan kebutuhan dari daya yang disediakan oleh mesin memungkinkan untuk desain mesin pembakaran lebih kecil, lebih ringan, dan lebih efisien.

Selain itu, diperlukan juga pembahasan tentang teknologi sensor yang terintegrasi dengan teknologi mobil listrik, yang akan dijelaskan secara lebih detail dalam Sub-bab 3.2.3 di bawah ini:

\section{Teknologi Sensor}

Pembahasan teknologi sensor hanya difokuskan pada beberapa sensor lingkungan sekitar kendaraan (Radar, Lidar, Ultrasonik dan Kamera) yang dimanfaatkan sebagai alat bantu dalam mendeteksi obyek atau benda yang ada di sekitar mobil dengan jarak tertentu untuk penerapan kendaraan otomatis (autonomous vehicle) sebagai kelanjutan dari program KBL.

\section{Radar}


Radio Detection and Ranging (Radar) merupakan teknologi deteksi objek dan jarak memanfaatkan pantulan gelombang radio. Panjang gelombang yang dipancarkan oleh radar sangat bervariasi. Dalam sistem radar umum digunakan frekuensi $24 \mathrm{GHz}$ atau $77 \mathrm{GHz}$. Setiap panjang gelombang atau frekuensi memiliki keunggulannya masing-masing. Frekuensi $77 \mathrm{GHz}$ mempunyai keunggulan dengan akurasi jarak yang tinggi dan pengukuran kecepatan yang lebih presisi. Sedangkan keuntungan menggunakan frekuensi $24 \mathrm{GHz}$ adalah kebutuhan antena yang lebih kecil sehingga meminimalisir terjadinya interferensi baik ke luar maupun ke dalam sistem. Perbedaan mendasar dalam pengaplikasian teknologi radar yang digunakan sebagai deteksi dengan jarak pendek, menengah atau jauh. Untuk jarak pendek pemanfaatan radar dapat digunakan sebagai sistem pembantu parkir, deteksi jalur/lorong, deteksi blind spot, kontrol jarak otomatis, alat pandu pengereman dan lain sebagainya. Untuk jarak menengah atau jauh radar bisa dimanfaatkan untuk mengidentifikasi situasi bahaya dan mencegah tabrakan.

\section{Lidar}

Lidar (Light Detection and Ranging) dapat mendeteksi objek sekitar dengan memanfaatkan pantulan cahaya. Teknologi lidar dapat dimanfaatkan untuk mengukur properti cahaya yang tersebar dan menemukan jarak atau informasi lain dari target yang jauh. Sumber cahaya yang digunakan adalah radiasi cahaya yang dihasilkan oleh laser. Laser akan mengirimkan (TX) berkas sinar ke objek yang nantinya dipantulkan dan diterima oleh penerima (RX) yang peka terhadap cahaya laser. Cahaya laser yang dikirimkan berada di dimensi cahaya tampak ataupun cahaya tak tampak berupa pancaran dan penerima inframerah.

\section{Ultrasonik}

Prinsip kerja perangkat ultrasonik hampir sama dengan teknologi Radar dan Lidar. Ada perbedaan frekuensi yang digunakan, di mana teknologi ultrasonik menggunakan pancaran dan penerima suara ultra dengan rentang frekuensi di atas rentang suara yang dapat didengar oleh manusia atau $>20 \mathrm{kHz}$. Perangkat ultrasonik akan memancarkan sinyal yang digunakan untuk mengukur jarak terhadap objek di depannya.

\section{Kamera}

Teknologi kamera yang ditanamankan dalam mobil listrik adalah kamera berjenis kamera 360 derajat untuk menangkap gambaran langkap kondisi sekitar mobil. Kamera bisa disebut sebagai mata tambahan pengemudi untuk melihat situasi di sekitar mobil. Hasil yang didapat oleh kamera dapat langsung ditayangkan di monitor pengemudi, atau dengan bantuan sistem pengolahan citra digital dapat secara otomatis mendeteksi objek sekitar dan memberi masukan pada sistem kontrol yang selanjutnya dieksekusi oleh unit aktuator. Untuk pengembangan teknologi yang lebih tinggi, penerapan sensor kamera ini dapat membantu dalam merealisasikan sistem kendaraan otomatis (Autonomous Vehicle).

Teknologi kendaraan otomatis mungkin bisa menjadi kelanjutan program KBL di masa mendatang, namun faktor keselamatan harus menjadi perhatian utama. Di bawah ini diberikan sedikit paragraf sebagai penjelasan tambahan terkait teknologi ini.

\section{Teknologi Kendaraan Otomatis [12]}

Dalam teknologi kendaraan otomatis, mobil dapat mengemudi dengan bantuan sedikit atau tanpa kendali manusia. Mobil diintegrasikan dengan perangkat keras (hardware) dan perangkat lunak (software) yang di dalamnya telah terprogram dan tertanam sistem cerdas. Autonomous vehicle atau kendaraan otomatis menggabungkan berbagai macam sensor serta menganalisis data sensor tersebut yang kemudian dapat mendeteksi dan membedakan objek yang berada di lingkungan sekitar kendaraan. Dari hasil analisa data tersebut mobil dapat membedakan objek seperti manusia/pejalan kaki ataupun benda lain yang berada di sekitarnya untuk menghindari kecelakaan yang tidak diinginkan. Metode pengaturan kendali autonomous vehicle menggunakan integrasi perangkat keras dan perangkat lunak yang memanfaatkan algoritma sistem kecerdasan buatan berupa machine learning dan deep learning, sehingga sistem dapat belajar dan mempelajari berbagai objek dan perilaku kendaraan di berbagai kondisi.

Mengingat banyak perangkat lunak yang sulit untuk digunakan serta sedikit yang dapat belajar, ada beberapa perangkat lunak yang telah dianggap bisa untuk memenuhi kebutuhan sistem mobil otomatis, seperti JESS (Java Expert System Shell) yang dikembangkan oleh Ernest Friendmant-Hill di 
Sandia National Laboratories, FuzzyClips \& FuzzyJ yang dikembangkan oleh oleh National Research Council (NRC) Canada, Subsumption Architecture yang dikembangkan oleh Brooks, AuRA (Autonomous Robotic Architecture) yang diproduksi oleh The MissionLab, ARL/PSU oleh The Applied Research Laboratory Pennsylvania University, Jet Propulsion Labs ASE oleh The Applied Science Craft Experiment, SOAR dan ACTR oleh Cognitive Architecture, dan NIST RCS. Semua sistem tersebut dibangun dengan menggunakan salah satu atau gabungan dari bahasa pemrograman Java, C, C++, LISP, dan lainnya.

Sistem lain yang sudah banyak digunakan adalah ADAS (Advanced Driver Assistant System). ADAS memungkinkan mobil bergerak semi otomatis. Dikatakan semi-otomatis karena gerakan mobil masih selalu dalam pantauan pengemudi/operator meskipun sudah berjalan sendiri sesuai algoritma yang diberikan. Sementara sistem akan memberikan arahan dan peringatan kepada pengemudi/operator bila ada informasi yang penting atau meminta persetujuan dari pengemudi.

\section{Dukungan Pemerintah Indonesia Terhadap Mobil Listrik}

Pemerintah sangat serius dalam mendorong berkembangnya industri teknologi mobil listrik. Salah satu caranya, dengan memberikan insentif kepada industri dalam rangka percepatan program kendaraan berbasis listrik (KBL) atau berbasis baterai. Hal ini tertuang dalam Perpres No. 55/2019 tentang Percepatan Program KBL Berbasis Baterai untuk Transportasi Jalan [13].

Insentif yang dimaksud antara lain insentif bea masuk atas impor KBL berbasis baterai yang disebut dengan completely knock down (CKD) atau incompletely knock down (IKD) atau komponen utama untuk jumlah dan jangka waktu tertentu. Insentif lain juga dapat berupa insentif Pajak Penjualan Atas Barang Mewah (PPnBM) yakni pembebasan atau pengurangan pajak pusat dan daerah; bea masuk importasi mesin, barang, dan bahan dalam rangka penanaman modal; penangguhan bea masuk dalam rangka ekspor; dan insentif bea masuk ditanggung pemerintah atas impor bahan baku dan bahan penolong untuk proses produksi.

Lebih lanjut, terdapat pula insentif untuk pembuatan peralatan satuan pengisian kendaraan listrik umum (SPKLU), insentif pembiayaan ekspor, insentif fiskal untuk riset dan pengembangan, tarif parkir, keringanan biaya pengisian listrik di SPKLU, dukungan pembiayaan pembangunan SPKLU, sertifikasi kompetensi bagi SDM KBL berbasis baterai, dan sertifikasi produk serta standar teknis bagi perusahaan industri KBL berbasis baterai. Adapun insentif non-fiskal yang dapat diberikan antara lain pengecualian dari pembatasan penggunaan jalan tertentu, pelimpahan hak produksi atas teknologi terkait KBL berbasis listrik, dan pembinaan keamanan operasional sektor industri. Terakhir, terdapat insentif fiskal dan non-fiskal tambahan bagi industri KBL bermerek nasional.

Dengan terbitnya Perpres No. 55/2019 tentang Percepatan Program Berbasis Baterai untuk Transportasi Jalan tersebut, pemerintah berkomitmen dalam pengembangan sistem energi transportasi yang mengarah pada kebijakan kendaraan berbasis listrik (KBL). Yang mendasari komitmen pemerintah untuk peralihan kendaraan konvensional ke KBL disebabkan oleh teknologi baru atas energi transportasi untuk mengantisipasi proyeksi permintaan bahan bakar minyak yang semakin besar. Dampak utama dari peralihan massal transportasi jalan raya ke mobil listrik adalah terjadinya peningkatan kebutuhan energi listrik dalam skala besar.

Sebagai percepatan program KBL, diperlukan dukungan semua pihak agar dapat mengurangi faktor penghambat yang menjadi pertimbangan preferensi konsumen dalam memilih KBL, yaitu harga, perawatan, dan daya tahan kendaraan serta kesiapan infrastruktur. Melalui fungsi pengawasan, DPR dapat berperan untuk memastikan percepatan konversi kendaraan konvensional ke KBL berjalan dengan baik yang didukung oleh kesiapan infrastruktur pendukungnya. Selain itu DPR juga berperan memastikan kinerja pemerintah dalam pemberian insentif bagi industri dan masyarakat pengguna KBL secara tepat sasaran [14].

Sebagai tindak lanjut khusus dari Perpres 55/2019, Peraturan Gubernur (Pergub) Nomor 3 tahun 2020 tentang insentif pajak Bea Balik Nama Kendaraan Bermotor (BBN-KB) atas Kendaraan Bermotor Listrik Berbasis Baterai diharapkan memacu populasi kendaraan setrum di ibu kota. Karena dengan adanya aturan tersebut, kini semua motor maupun mobil listrik murni di wilayah DKI Jakarta (contoh penerapan wilayah), tidak akan dikenakan pajak BBN 12,5 persen. Ya, seperti tertuang salam Bab II Pasal ayat 2, seluruh kendaraan listrik berbasis baterai tidak akan dikenakan pajak BBN. Benefit lain 
khusus bagi yang memiliki mobil listrik juga dipastikan akan terbebas dari kebijakan ganjil genap di Jakarta [15].

\section{Kelemahan-kelemahan Mobil Listrik Dibandingkan dengan Mobil Konvensional [16, 17]}

Meski memiliki sejumlah kelebihan, ternyata teknologi mobil listrik juga memiliki banyak kelemahan atau kekurangan. Kelemahan-kelemahan ini bisa dikelompokkan dalam 3 kategori utama, yakni biaya operasional, kelengkapan infrastruktur, dan performansi atau daya tempuh. Untuk kategori biaya operasional, mobil listrik bisa menjadi mahal disebabkan oleh tiga hal: baterai (waktu pengisian baterai masih lama, bisa memakan waktu antara 4-6 jam hingga penuh dengan jarak tempuh $160 \mathrm{~km}$, meskipun ada juga mobil listrik yang memiliki kapasitas baterai $38,3 \mathrm{kWh}$ dan dapat diisi ulang hingga $80 \%$ hanya dalam waktu 57 menit, disebut fast-charging (50-kW) dengan jarak tempuh $373 \mathrm{~km}$ ), daya listrik rumah, dan pajak kendaraan mobil listrik. Dari segi kelengkapan infrastruktur, yakni kurangnya tempat pengisian bahan bakar umum mobil listrik, dan karena kebutuhan listrik yang cukup besar maka hanya bisa dinikmati oleh daerah-daerah tertentu terutama di kota-kota besar yang memiliki jaringan kelistrikan yang lebih stabil. Sedangkan dari segi performansi dan daya tempuh, ini bersifat trade-off. Di satu sisi, dari segi dimensi yang kecil membuat mobil listrik jadi lebih dinamis, namun hanya cukup untuk dua orang penumpang (belum pas untuk mobil keluarga). Sedangkan bila bersifat mobil penumpang (seperti $S U V$ yang bertenaga listrik murni), dapat menempuh jarak sejauh $405 \mathrm{~km}$ dengan satu kali pengisian daya baterai penuh, namun harganya yang masih kurang terjangkau khalayak ramai.

\section{KESIMPULAN}

Penggunaan mobil listrik pertama telah diperkenalkan pada tahun 1828 dan diproduksi pertama pada tahun 1884. Secara garis besar terdapat dua jenis utama dari mobil listrik yaitu Battery Electrical Vehicle (BEV) dan Plug-in Hibrid Electrical Vehicle (PHEV). Di mana BEV merupakan mobil listrik yang hanya mengandalkan energi yang tersimpan dalam kemasan baterai. Sedangkan PHEV merupakan gabungan dari mobil yang memiliki dua sumber energi yaitu energi listrik yang tersimpan pada baterai dan sumber energi dari pembakaran bahan bakar minyak.

Pemerintah Indonesia sangat mendukung pengembangan dan pemasaran mobil listrik dengan diterbitkannya Perpres No. 55 Tahun 2019 tentang Percepatan Program Berbasis Baterai untuk Transportasi Jalan. Pemerintah berkomitmen dalam pengembangan sistem energi transportasi yang mengarah pada kebijakan kendaraan berbasis listrik (KBL). Salah satu cara agar masyarakat tertarik menggunakan kendaraan berbasis listrik (KBL) seperti mobil listrik adalah dengan cara memberikan insentif seperti pengurangan pajak kendaraan dan bersifat bebas dari program ganjil genap di jalan raya seperti di ibukota negara.

Namun, di samping itu, pemanfaatan teknologi seperti radar, lidar, ultrasonik, dan kamera (berbagai macam sensor) untuk mengetahui objek yang ada di sekitar mobil yang dapat diintegrasikan dengan perangkat lunak (software) yang terprogram dan tertanam pada sistem cerdas, maka akan dapat menggantikan posisi manusia sebagai pengendali dan menjadikan kendaraan otomatis (autonomous vehicle). Teknologi ini juga diharapkan bisa menjadi kelanjutan dari program KBL dan sebagai solusi mengurangi carbon footprint di masa mendatang.

\section{DAFTAR PUSTAKA}

[1] Arahan Jokowi, Ibu Kota Baru Eksklusif Mobil Listrik-Otonom, Tersedia di Internet : https://www.cnnindonesia.com/teknologi/20200116181124-384-466028/arahan-jokowi-ibu-kota-barueksklusif-mobil-listrik-otonom (Diakses pada 4 Maret 2020)

[2] Perkembangan Jumlah Kendaraan Bermotor Menurut Jenis, 1949-2018, Tersedia di Internet : https://www.bps.go.id/linkTableDinamis/view/id/1133 (Diakses pada 4 Maret 2020)

[3] AirVisual: Paling Berpolusi, Udara Jakarta Pagi Ini Sangat Tidak Sehat! Tersedia di Internet : https://news.detik.com/berita/d-4667683/airvisual-paling-berpolusi-udara-jakarta-pagi-ini-sangattidak-sehat (Diakses pada 4 Maret 2020)

[4] Resosudarmo, B.P., D.A. Nurdianto, and A.A. Yusuf (2009), "Greenhouse Gas Emission in Indonesia: The Significance of Fossil Fuel Combustion", in B. Robiani, B.P. Resosudarmo, A.A. Alisjahbana, and A. Rosa (eds.), Regional Development, Energy and the Environment in Indonesia, Palembang: Indonesian Regional Science Association, pp. 146-159 
[5 MDPI (2017), A Comprehensive Study of Key Electric Vehicle (EV) Components, Technologies, Challenges, Impacts, and Future Direction of Development, Agustus 2017

[6] https://www.ifixit.com/Device/1997-2000_Toyota_Prius (Diakses pada 4 Maret 2020)

[7] IRENA (2017), Electric Vehicles: technology brief, International Renewable Energy Agency, Abu Dhabi., Februari 2017

[8] Grunditz, E.A. and Thiringer, T. Performance Analysis of Current BEVs Based on a Comprehensive Review of Specifications. IEEE Trans. Transp. Electr. 2016, 2, 270-289

[9] Y. Miao, P. Hynan, A. von Jouanne, A.Yokochi, Current Li-Ion Battery Technologies in Electric Vehicles and Opportunities for Advancements. Energies 2019, 12, 1074

[10 T. Markel dan A. Simpson, "Cost-Benefit Analysis of Plug-in Kendaraan Teknologi Hibrid Listrik," 22 International Electric Vehicle Symposium, Yokohama, Jepang. Oktober 2006.

[11 Hybrid Electrical Vehicles, Tersedia di Internet : http://www.ae.pwr.wroc.pl/filez/20110606094057_HEV.pdf (Diakses pada 4 Maret 2020)

[12] Nuryanto, E., Muhammad, K. (2018). Tinjauan Pengembangan Mobil Listrik Menuju Teknologi Autonomous Vehicle, Tersedia di internet:

https://www.researchgate.net/publication/331370613_Tinjauan_Pengembangan_Mobil_Listrik_Menuj u_Teknologi_Autonomous_Vehicle (Diakses pada 03 Mei 2020)

[13] Pemerintah Dorong Industri Mobil Listrik, Ini Deretan Insentifnya, Tersedia di Internet : https://otomotif.tempo.co/read/1236301/pemerintah-dorong-industri-mobil-listrik-ini-deretaninsentifnya/full\&view $=$ ok (Diakses pada 04 Maret 2020)

[14] A. Wirabrata (2019) Percepatan Program Kendaraan Bermotor Listrik Di Indonesia, Tersedia di Internet : https://peraturan.bpk.go.id/Home/Details/116973/perpres-no-55-tahun-2019 (Diakses pada 03 Mei 2020)

[15] https://kumparan.com/kumparanoto/5-harga-mobil-listrik-di-indonesia-mana-yang-terjangkau1siBtsyVi6f (Diakses pada 15 Mei 2020)

[16] Luthfi Parinduri, Yusmartato, Taufik Parinduri, (2018) Kontribusi Konversi Mobil Konvensional Ke Mobil Listrik Dalam Penanggulangan Pemanasan Global, Tersedia di Internet : https://jurnal.uisu.ac.id/index.php/jet/article/view/551, (Diakses pada 03 Mei 2020)

[17] https://www.cnnindonesia.com/teknologi/20191227121955-384-460330/indonesia-diserbumobil-mobil-listrik-pada-2020 (Diakses pada 15 Mei 2020) 